\title{
Volume 41, 1997 (Corrected)
}

\section{Compiled by Edward Swanson}

Editor's note: Due to a production error, the index for Volume 41 that was published in the October 1997 issue of LRTS was the preliminary version, not the final version. It had been prepared before the October issue was in its final form, and $\mathrm{Mr}$. Swanson had not had an opportunity to review and update the index based on the final form of the October issue before it was published. We regret this error and apologize to Mr. Swanson for its occurrence. The correct version of the index appears below.

General Procedures Used in Compiling the Index

The following types of entries are included:

a. authors - of articles, reviews, and letters

b. titles—of articles and of articles about which letters were published

c. subjects - of articles and of books reviewed

Subject entries for individuals are identified by "(about)"; letters are identified by " $(c)$ ".

Reviews are indexed by name of reviewer and by subject of the work reviewed, identified by

" $(r)$ ". They are also listed by title under the heading "Books reviewed".

Entries are arranged word by word following the "file-as-spelled" principle. Numbers are arranged

before alphabetical characters; acronyms without internal punctuation are arranged as words.

Paging of Volume 41:

Pages $1-72=$ Number 1 (January)

Pages $73-172=$ Number 2 (April)

Pages 173-276 = Number 3 (July)

$\mathbf{A}$

Academic libraries

Mutilation of materials in: 7-16

Use of paraprofessional staff members in: 205-18

Acquisition of library materials Management of: $136-38,143-45,155-57$

"The Adequacy of the Structure of the National Library of Medicine Classification Scheme for Organizing Pharmacy Literature" 123-35

"Analyzing Search Styles of Patrons and Staff: A Replicative Study of Two University Libraries" 219-35

"Arranging Roots: Classification and Subject Headings for Genealogical Collections" $335-46$
Art materials

Mutilation of: 7-16

Author records

Arrangement of: 79-100

Authority management: $39-49$

\section{$\mathbf{B}$}

Ball State University Libraries: 39-49

Bibliographic relationships: 79-100

Bibliographic works

Arrangement of in online catalogs: 79-100

Black, Steve: 283-94

Blake, Linda: 335-46

Boissonnas, Christian M.: 147-54

Books reviewed

Cataloger's Desktop: 347-49

Digital Imaging Technology for Preserva- 
tion (RLG Symposium, 1994; Elkington, ed.): $158-62$

Enhancing a New Design for Subject Access to Online Catalogs (Drabenstott): $60-67$

Geographic Information Systems and Libraries (Annual Clinic on Library Applications of Data Processing, 32d; Smith and Gluck, eds.): $67-70$

Information Services for Innovative Organizations (Maguire, Kazlauskas, and Weir): 58-60

Preservation Management (Feather, Matthews, and Eden): 162-64

RLG Digital Image Access Project (RLG Symposium, 1995; McClung, ed.): 15862

Scholarship in the New Information Environment (RLG Symposium, 1995; Hughes, ed.): 158-62

Selecting Library and Archive Collections for Digital Reformatting (RLG Symposium, 1995; Erway, ed.): 158-62

Serials Management (Chen): 164-66

Testing a New Design for Subject Analysis to Online Catalogs (Drabenstott and Weller): $60-67$

Using Subject Headings for Online Retrieval (Drabenstott and VizineGoetz): $60-67$

Brogdon, Jennie L.: 323-34

\section{C}

California Newspaper Project: 236-53

Call, J. Randolph: 155-57

Call numbers

Acceptance of on cataloging copy: 29-38

Carlyle, Allyson: 79-100, 273 (c), 350-51 (c)

Cataloging

By paraprofessional staff: 205-18

Costs: 29-38

"Celebrating C. Sumner Spalding" 274-75

Chan, Lois Mai: 295-322

Chang, Sherry S.: 50-57

"Change and Decay" 143-45

"Changing Acquisitions at Detroit Public Library" 155-57

"Changing Roles: Original Cataloging by Paraprofessionals in ARL Libraries" 205-18

"Chemistry Journal Use and Cost: Results of a Longitudinal Study" 101-11, $350(\mathrm{c})$

Chemistry materials Costs: 101-11

Use studies: 101-11

Chrzastowski, Tina E.: 101-11, 350 (c)

City University of New York, Baruch College: $139-42$

Classification

Genealogical materials: 335-46
Pharmacy materials: 123-35

Collection analysis: 50-57

"A Comparison of Pre- and Post-Cataloging Authority Control" 39-49

"Consortium Use of the OCLC/AMIGOS Collection Analysis CD: The SUNY Experience" 50-57

"Converting Wade-Giles Cataloging to Pinyin: The Development and Implementation of a Conversion Program for the Australian National CJK Service" 254-63

Conway, Paul: 158-62 (r)

Cooperative cataloging Saudi Arabia: 264-72

"Cooperative Cataloging: Prospects and Problems for Libraries in Saudi Arabia" 264-72

Copyright status

Determining for preservation purposes: $323-34$

Cornell University: 147-54

Crotteau, Mark: $350(c)$

"Cutting Cataloging Costs: Accepting LC Classification Call Numbers from OCLC Cataloging Copy" 29-38

\section{D}

"Data Entry and the Economy of Offshore Information Production" 112-22

Data entry industry: 112-22

"Database Design for Preservation Project Management: The California Newspaper Project" 236-53

Daugherty, Robert Allen: 172 (c)

Demas, Samuel: 323-34

"Determining Copyright Status for Preservation and Access: Defining Reasonable Effort" $323-34$

Detroit Public Library: 155-57

Digital imaging: 158-62 $(r)$

Dodd, David C.: $172(c)$

Dole, Wanda V: : 50-57

Duchin, Douglas: 139-42

Duke, Jolen K.: $347-49(r)$

\section{$\mathbf{E}$}

Ellis, Steven: 112-22

"Errors and Obsolete Elements in Assigned Library of Congress Subject Headings: Implications for Subject Cataloging and Subject Authority Control" 295-322

\section{$\mathbf{F}$}

Filing order

In online catalogs: 79-100

Form/Genre terms: 190-204

Frangakis, Evelyn; 167-68

"From Access Points to Materials: A Transaction Log Analysis of Access Point Value 
for Online Catalog Users" (Wyly, July 1996): 172 (c)

"From Citation to Piece in Hand: The Search for Efficiency in Accessing Monographic Series" 179-89

"Fulfilling the Second Objective in the Online Catalog: Schemes for Organizing Author and Work Records into Usable Displays" 79-100, 273 (erratum), $350(c), 350-51(c)$

\section{G}

Geer, Beverley: 164-66 (r)

Genealogical materials Classification of: 335-46

Subject headings for: $335-46$

Geographic information systems: $67-70(r)$

Gossen, Eleanor: 17-28

Gozzi, Cynthia: 136-38

Graham, Crystal: 350 (c)

"Grass-Roots Cataloging and Classification: Food for Thought from World Wide Web Subject-Oriented Hierarchical Lists" (Dodd, July 1996): 172 (erratum)

Greever, Karen E.: 39-49

Groom, Linda: 254-63

\section{H}

Hayman, Lynne M.: 236-53

Hiatt, Robert M.: 274-75

\section{I}

"Identical in Appearance but Not in Actuality: Headings Shared by a Subject-Access and a Form/Genre Access Authority List" 180-204

"In Memoriam: Susan Garretson Swartzburg (1938-1996)" 167-68

Information services: 58-60 $(r)$

"Instructions for Authors" 71-72

Interlibrary loan: 17-28

\section{J}

"Journal Collection Analysis at a Liberal Arts College" 283-94

\section{$\mathbf{K}$}

Kaczor, Sue: 17-28

Khurshid, Zahiruddin: 264-72

Kingsley, Peter: 143-45

\section{$\mathbf{L}$}

Lang, Mary S.: 219-35

Leazer, Gregory H.: 58-70, 158-66, 347-49

Library of Congress subject headings

Errors in assignment of: $295-322$

Obsolete elements of: $295-322$
Lopez-Mertz, Elsa M.: 123-35

M

Maddox, Anthony B.: 58-60 (r)

Malinconico, S. Michael: 29-38

"Managing Acquisitions in a Changing Environment: From Coping to Control" 136-38

"Managing Technical Services in a Changing Environment: The Cornell Experience" 147-54

Massey, Susan A.: 29-38

Miller, David: 180-204

Mohr, Deborah A.: 205-18

Monographic series Access to: $179-89$

“Monographs Acquisitions: Staffing Costs and the Impact of Automation" (Morris, Rebaracak, and Rowley, Dec. 1996): 169-71 (erratum)

"Moving Right Along: Changes in Staffing, Functions, Workstation Setup, and Personnel" 139-42

Mutilation of library materials: 7-16

\section{$\mathbf{N}$}

National Library of Australia: 254-63

National Library of Medicine classification: 123-35

New York University: 143-45

Newspapers Preservation of: 236-53

"Notes on Operations" 50-57, 136-57, 236$72,335-46$

\section{O}

OCLC bibliographic records: 29-38

OCLC/AMIGOS Collection Analysis CD: 50-57

Ogden, Sherelyn: 162-64 (r)

Olesko, Brian M.: 101-11

Olszak, Lydia: 7-16

Online catalogs

Displays in: 79-100

Filing order in: 79-100

Searching in: 219-35

Subject access in: 60-67 ( $r)$

\section{$\mathbf{P}$}

Paraprofessional staff members Use of for cataloging: 205-18

Paris Principles: 79-100

Pharmacy materials Classification of: 123-35

Pinyin romanization scheme Conversion from Wade-Giles: 254-63

Preservation of library materials: 158-62 ( $r)$ Management of-Great Britain: 162-64 $(r)$ Use of databases in: 236-53 
$\mathbf{R}$

Ray, Kathlin L.: 219-35

\section{$\mathbf{S}$}

Schuneman, Anita: 205-18

Science materials

Interlibrary loans of: 17-28

Scilken, Marvin H.: 273 (c)

Serial publications: 165-66 $(r)$

Analysis of collections of: 283-94

Costs: 101-11

Use studies: 101-11, 283-94

Series, see Monographic series

Shemberg, Marian: 179-89

Smith, Elizabeth H.: 7-16

Spalding, C. Sumner: 274-75 (about)

Stallings, Evelyn T:: 335-46

State University of New York: 50-57

State University of New York, University at Albany: 17-28

Subject access

In online catalogs: $60-67(r)$

Subject headings: 190-204

Genealogical materials: $335-46$

Swanson, Edward: 352-55

Swartzburg, Susan Garretson: 167-68 (about)
$\mathbf{T}$

Technical services departments Management of: 139-42, 147-54

Transaction log studies: 219-35

"Treatment of Mutilated Art Books: A Survey of Academic ARL Libraries" 7-16

U

University of Alabama Libraries: 29-38

University of North Carolina at Charlotte: 136-38

University of the Pacific: 219-35

V

"Variation in Interlibrary Loan Use by University of Albany Science Departments" 17-28

Vizine-Goetz, Diane: 295-322

\section{W}

Wade-Giles romanization scheme

Conversion to Pinyin: 254-63

Weinberg, Bella Hass: 60-67 (r)

Wiberley, Stephen E., Jr.: $172(c)$

Workstations: $139-42$

\section{$\mathbf{Z}$}

Zimmerman, Ann: 67-70 $(r)$

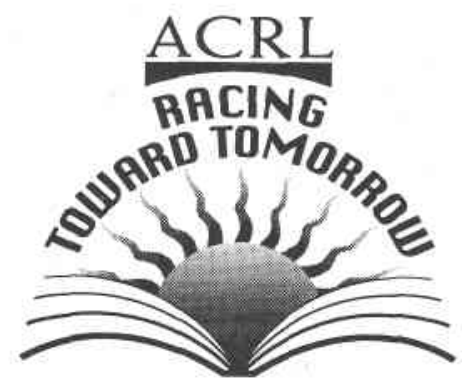

ACRL 9th National Conference

Detroit

April 8-11, 1999

\section{Call for Participation}

We're on the fast track for change as we are Racing Toward Tomorrow. How can academic librarians create and channel change? Shift your gears and share your expertise as a presenter in these areas:

te creating lifelong learners

te shaping the changing environment

te changing work roles

te developing alternate resources

ie. expanding knowledge base

te creating alliances and partnerships

For details about preparing a proposal and additional information about the conference, visit ACRL's Web site athttp://www.ala.org/acrl/prendex.html

Or call (800) 545-2433, ext. 2514

Or e-mail acrl@ala.org

Association of College and Research Librarles, 50 East Huron St., Chicago, IL 60611 